\title{
Regional Aspects of Business Environment Creation in the SME Segment in Slovakia
}

\author{
Jaroslav Belás \\ Tomas Bata University in Zlín, Faculty of Management and Economics, Czech Republic \\ E-mail: belas111@gmail.com \\ Juraj Sipko \\ Paneuropean University, Faculty of Economics and Business, Slovak Republic \\ E-mail: jurajsipko@gmail.com \\ Yuriy Bilan \\ University of Szczecin, Faculty of Economics Science and Management, Poland \\ E-mail: yuriy_bilan@yahoo.co.uk
}

\section{Doi:10.5901/mjss.2015.v6n3p637}

\section{Abstract}

The aim of this article is to define, quantify and compare the significant attributes of creation and development of the business environment for small and medium-sized enterprises (SMEs) in selected regions of Slovakia. Within this stated objective, relevant factors and business relationships between entrepreneurs and the socio-economic system were analysed. The entrepreneurs' perception of their environment (state, company, banks etc.) was evaluated. The data was collected through a questionnaire. The whole research was conducted in the Bratislava region on a sample of 102 SMEs, in the region of Trencin on a sample of 105 SMEs and in the Zilina region on a sample of 168 SMEs. Thus we compared important factors of business environment in the most economically developed region of the Slovak capital to the average regions of Trencin and Zilina. Entrepreneurs stated a quality of not being afraid to risk as the most essential characteristic feature of a businessman. The following qualities were mentioned as well: expertise, responsibility and persistence.. The largest number of entrepreneurs in all the regions of Slovakia said that the state institutions just bully them and create unnecessary obstacles. Entrepreneurs indicated that commercial banks' approach to SMEs financing remains problematic.

Keywords: Small and Medium-Sized Enterprises, regional differences, characteristics of entrepreneurs, relationship with the State, relationship with banks

\section{Introduction}

Small and medium-sized enterprises (SMEs) have specific features and fulfill important tasks in an economic system. SMEs significantly contribute to higher employment and GDP, help to create a more intensely competitive environment which has great importance in relation to price and quality of products and services. SMEs help with their flexibility to fill the market space and they are bearers of important innovations. Moreover, SMEs must fight for customers and must seek the best location for them in the market.

SMEs play an important role in the economic system of Slovakia as well. In this country, the share of SMEs in the total number of active enterprises was $99.2 \%$; in the total employment it was $59.5 \%$. The share of added value was $55.6 \%$ and the share of SMEs in the profit before taxes was 51.6\% in 2012. (Národná agentúra pre rozvoj malého a stredného podnikania, 2013)

For the successful development of a company it is necessary to create favourable conditions for the growth of business awareness and shape a good quality of business environment and effective relationships between firms and their environment, i.e. society, the state, politicians, banks, etc.

In this article, significant attributes of the creation and development of the business environment of the SME segment in the selected regions of Slovak Republic were examined.

\section{Literature Review}

Current research papers intensively deal with entrepreneurship and business environment from many points of view, such as economic, institutional or cultural context, influence of gender and age on entrepreneurship, business orientation, 
customer orientation, financial risks, etc.

According to Cumming, Johan, and Zhang (2014), Gawel (2010) entrepreneurship has a significantly positive impact on the GDP/capita, exports/GDP and the number of patents per population, and a negative impact on unemployment rates. Their findings point to institutional and cultural impediments to the effectiveness of entrepreneurship. Institutional/legal barriers are likely to have a negative impact on entrepreneurship. These barriers influence the decision to become an entrepreneur.

Entrepreneurial orientation is also in question nowadays as it is considered to be an essential driver of the high financial performance of companies. Similarly, Soininen et al. (2012) consider innovativeness, risk-taking and proactivity as essential characteristics of entrepreneurial orientation. The results of their studies do not support the assumption that entrepreneurial orientation is positively related to the profitability of small firms. On the other hand, there is a positive relationship between the entrepreneurial orientation of a firm and a firm's pace of growth. According to Eggers et al. (2013), to drive itself to grow, a firm needs to deploy a strategy centered on entrepreneurial orientation or else risk stagnation occurs. In this regard, Lasagni (2012) indicates that innovation performance is higher in the SMEs that are proactive in strengthening their relationships with innovative suppliers, users and customers. Boso, Story and Cadogan (2013) argue that a high degree of entrepreneurial orientation maximalises company performance when operating in less developed countries.

Furthermore, customer orientation is considered to be an essential element for small firm success. (Brockman, Jones and Becherer, 2012). Their results support the overall positive influence of customer orientation on performance and indicate that the influence is stronger as risk-taking, innovativeness and opportunity focus increase.

Nonetheless, there are only a few studies dealing with regional aspects. One of them is a study by Stuetzer et al. (2014) that examines connections between regional characteristics and individual entrepreneurship. They found no empirical evidence for a direct effect of the regional characteristics on an individual's start-up intentions and engagement in the start-up activity. Their findings point to relevance of the indirect effects of the regional characteristics on individual entrepreneurship. Individual opportunity perception might play an important role in the cascading-down process of regional characteristics towards the individual. However, even inhabitants of one region can differ in their perceptions of business opportunities. This could be caused by several personal and social influences. Secondly, Simon-Moya at al. (2014) and Gallardo-Vazquez and Sanchez-Hernandez (2012) point out there are significant differences among business environments of various countries and even regions. The authors suggest that politicians in every single country have to adjust the trade laws to conditions of the respective country. The same laws in countries or regions with different economies can lead to totally different results.

Business activities are significantly determined by the environment of a company, which forces it to use a particular method of behaviour, to use the choice of particular business goals and ways of achieving them. In this context, a crucial role is played by social environment and political and legal environment that is created by state authorities.

As far as we know, there exist no papers examining regional aspects of the business environment creation in Slovakia. Exactly this is the reason why we decided to carry out our research.

The aim of this article was to define, quantify and compare the significant attributes of creation and development of the business environment for SMEs in the selected regions of Slovakia. Within this objective, relevant factors and business relationships between entrepreneurs and socio-economic system were analysed. The entrepreneurs' perception of their environment, i.e. society, state, banks or universities was evaluated.

In our research we compared important factors of business environment in the most economically developed region of the Slovak capital to the average regions of Trencin and Zilina. Our aim was to measure the regional differences of business environment in Slovakia.

\section{Methodology and Data}

The research on business environment was conducted in 2013 in the selected regions of Slovakia through a questionnaire survey. In the Bratislava region (BA), 102 SMEs have been reached; in the Zilina region (ZA), 164 SMEs have been reached and in the Trencin region (TN), 105 SMEs have been reached. Companies' data was provided by their owners.

The composition of these regions has been chosen because it enables us to compare business environment in the most economically developed region to the averagely developed regions. Our aim was to measure the differences among these regions and to define their significance.

The Bratislava region is located in the West and Southwest part of Slovakia. It has an area of 2,053 $\mathrm{km}^{2}$ which means it is the smallest region of Slovakia. The number of inhabitants was 628,686 and the unemployment rate was 5.4 
$\%$ in 2011. It borders the Trnava region in the North and the East, Hungary in the South and Austria in the West. The Bratislava region is the region with the best economic performance and creates $26 \%$ of the total Slovak GDP. As for the purchasing power parity expressed by the GDP/capita (24,000 EUR), it exceeds the EU25 average by $15.90 \%$. According to the data of Eurostat, the Bratislava region was the fifth richest region in the EU concerning GDP per capita in 2011. With 1.86 times the EU average, it overtook such regions as Stockholm, Prague or Vienna. The economy of the Bratislava region contains all the economic sectors based on the traditional industrial production of goods. The most important industrial sectors are the chemical, automotive, electronic and food industry and mechanical engineering. Over the last few years, the Bratislava region has become a European centre of automotive industry representing $30 \%$ of the overall Slovak export. (Bratislavský samosprávny kraj, 2014)

The Trencin region has an area of 4,502 km², has about 600,000 inhabitants, GDP per capita reached 10,744 EUR in 2010 and the registered unemployment rate was at 10.89\% in 2012 (significantly below the overall Slovak average of $14.44 \%)$.

The Zilina region has an area of $6,800 \mathrm{~km}^{2}$, total population is up to 700,000 and the population density is 102 inhabitants per $\mathrm{km}^{2}$. The unemployment rate was raised to $11.91 \%$ in 2011 . The GDP per capita was 10,794 EUR in 2011.

In our research in the Bratislava region, the largest share of surveyed companies was comprised of SMEs operating in trade activities (33\%), followed by construction firms (12\%), manufacturing companies (7\%), transport companies (1\%) and agricultural enterprises (1\%). The remaining share was formed by companies operating in other sectors.

In the Trencin region, the structure of companies was as follows: manufacturing companies (21\%), trade companies (21\%), construction companies (18\%), transport companies (4\%) and agricultural firms (5\%). The largest portion of companies operated in other sectors (31\%).

In the Zilina region, the structure of companies was as follows: $17 \%$ of companies operated in the manufacturing sector, $21 \%$ in the trade sector, $17 \%$ in the construction sector, $6 \%$ in the transport sector and $1 \%$ in the agricultural sector. The largest portion of companies operated in other sectors (38\%).

From the total number of 102 surveyed firms in the Bratislava region, $54 \%$ of them were doing business for more than 10 years, 19\% of them between 5 and 10 years, 27\% of them between 1 and 5 years. Therefore, it can be stated that the research was examining quite experienced entrepreneurs from this region. The size structure of companies was as follow: $83 \%$ were micro-enterprises, $12 \%$ were small enterprises and $5 \%$ were medium-sized companies.

From the total number of 105 surveyed companies in the Trencin region, 54\% of companies do their business more than 10 years, $25 \%$ do their business from 5 to 10 years and 21\% do their business from 1 to 5 years. The size structure of the companies was as follows: $62 \%$ were micro-enterprises, $31 \%$ were small enterprises and $7 \%$ were medium-sized enterprises.

In the Zilina region, of 164 surveyed companies 38\% do business more than 10 years, 32\% represents firms which do their businesses from 5 to 10 years and 30\% of surveyed companies do businesses from 1 to 5 years. Thus companies surveyed in this region were equally distributed from the perspective of business duration. As for the size structure, $66 \%$ was represented by micro enterprises, $20 \%$ were small companies and 14\% were medium-sized enterprises.

The business environment is also determined by personal characteristics of individual entrepreneurs. Creativity, risk taking and independence increase the probability of becoming an entrepreneur and decrease the probability of becoming an employee (Belas et al. 2014; Knörr, et al. 2013). Almeida et al. (2014) show that META model (Awareness, Vision, Creativity and Opportunism) is the strongest and most consistent predictor of entrepreneurial activity. Entrepreneurial individuals are characterised primarily as enterprising and creative, and to some degree as social and investigative.

As entrepreneurs have to perform various tasks, they do not need only knowledge, competence and expertise, but also a complex of skills and abilities influenced by their personality. These are for example risk tolerance, emotional stability or an internal control helping them to trust their decisions (Caliendo, Fossen and Kritikos, 2014). In this context, Ilouga, Mouloungni and Sahut (2014) point out that the commitment to the profession of an entrepreneur is considered as long, complicated, loaded with obstacles, difficult to achieve, and requires the vocational skills that will enable the person to protect his or her goal from distractions, to persevere and to optimise the plausibility of achieving it. Entrepreneurs must demonstrate some resistance against the uncertainty concerning the future through their self-motivation, selfdetermination and initiative so as to overcome their fears and worries.

According to Deáková et al. (2010), Sobeková et al. (2014) the most important personal qualities for an entrepreneur are: courage, self-reliance, responsibility, determination, perseverance, proactiveness, creativity and 
scholarship in the particular area in which this businessman intends to do business.

Kvietok (2013) adds that a decision to take on business risks is symptomatic for a certain type of people, in more detail for individuals who are more risk tolerant are more likely to start up firms (Hvide, and Panos, 2014).

In line with the findings of previous research, we hypothesize the following:

$\mathrm{H1}$ : The most important feature of an entrepreneur is not being afraid of taking risks.

H1a: The differences in the perception of the above mentioned key characteristics of an entrepreneur are not significant within the selected regions.

Generally, Slovak entrepreneurs evaluate the approach of the State to their needs and interests negatively. For instance, the Business Environment Index in relation to Slovakia, which is prepared by the Business Alliance of Slovakia, fell in 2011 to the historically lowest level since 2001 (Podnikatel'ská aliancia Slovenska, 2012).

Business environment in Slovakia was negatively perceived by 56\% of companies in 2013. This results from the economic survey of the Slovak Chamber of Commerce (2014) among its members, which regularly takes place at the end of the year. A positive evaluation was showed only by $2 \%$ of respondents and the remaining $42 \%$ declared that the business environment has not changed compared since 2012. The national economic policy was negatively rated by $44 \%$ of respondents, while in the year on year comparison, negative evaluations decreased by 6 percentage points. Only $4 \%$ of business entities perceived the government measures as positive and nearly a half, namely $48 \%$, assessed the economic policy neutrally. More than $38 \%$ of respondents suggested to the government taking actions in the field of tax burden and reducing administrative burden. Participants in the survey suggested, for example, returning to a flat rate of income tax, reducing the rates of Value Added Tax, or taking effective measures against tax evasion. Approximately 33\% of business subjects required fundamental improvements in law enforcement and taking measures to accelerate solutions of commercial disputes. The greatest risks to businessmen were the following: high tax burden, poor law enforcement or cronyism and corruption in public procurement (Slovenská obchodná a priemyselná komora, 2014).

Therefore, we hypothesize the following:

$\mathrm{H} 2$ : More than $50 \%$ of entrepreneurs think the State only bullies them and does not help them in their business activities.

$\mathrm{H} 2 \mathrm{a}$ : The differences in the assessment of the State's approach are not significant within the selected regions.

H3: More than $60 \%$ of entrepreneurs think it is right that the State supports them financially.

H3a: There are no regional differences in the assessment of the State's financial support.

H4: The reception of the State financial support in the regions of Trencin and Zilina is higher than $20 \%$.

$\mathrm{H} 4 \mathrm{a}$ : The reception of the State financial support is significantly higher in the regions of Zilina and Trencin than in the region of Bratislava.

The financial gap represents an extremely significant problem of SMEs since many of these companies have very limited access to external financial resources (European Commission, 2011).

Lofstrom, Bates and Parker (2014) state that an entry into the low-barrier lines of business requires only modest amounts of financial capital and little in the way of owner advanced educational credentials, while in high-barrier fields, potential entrepreneurs typically need to assemble substantial capital and the skill requirements facilitating successful operation are often high.

Di Giuli, Caselli and Gatti (2011) state that for small and medium-sized enterprises the credit availability is a vital element for their development. Covaci (2008) adds that SMEs are perceived as being more risky than big companies because they show a higher sensitivity to economic shocks while disposed to an inferior capacity to absorb variations.

In this context, many researchers, such as Dierkes et al. (2013), Kirschenmann and Norden (2012), and Neuberger and Räthke (2009) present that companies in the segment of SME are smaller, more informationally opaque, riskier and more dependent on trade credit and bank loans. According to Canales and Nanda (2012), small businesses, and particularly young small businesses, have little internal cash flow to finance their operations and are also associated with significant asymmetric information.

According to Moro and Fink (2012), banks play an essential role in business financing, especially SMEs, since they have more difficulty accessing equity capital markets. The process used by banks to decide whether and how much to lend relies on different lending technologies and banks usually tend to use more than one technology at a time.

Several research papers on the banking sector come to the conclusion that commercial banks have tightened their lending policies as a result of the global financial crisis. On the other hand, Cumming, Johan and Zhang (2014) argue that the impact on entrepreneurship is significantly mitigated by excessively strong creditor rights that limit the entrepreneurial risk taking.

In line with the findings of previous research, we hypothesize the following:

H5: Less than $50 \%$ of entrepreneurs assess the commercial banks' approach towards them positively. 
H5a: The assessment of the commercial banks' approach is more negative in the regions of Trencin and Zilina than in the region of Bratislava.

The associations in contingency tables were analysed by Pearson statistics for count data. P-value was being compared with standard a 5\% confidence level. P-value which is lower than this confidence level leads to the rejection of the null hypothesis. The null claims there is no association between variables. The calculations were performed in the statistical packages XL Statistics and R. The instruments of descriptive statistics, namely percentages and means were also used.

\section{Research Results and Discussion}

Table 1 contains crucial personal features, skills and abilities of an entrepreneur according to entrepreneurs themselves. The results of our research confirmed $\mathrm{H} 1$. In the entrepreneurs' point of view, the most important characteristic of an entrepreneur is not being afraid to take risks. Other frequently chosen qualities were expertise, responsibility and persistence.

H1a was confirmed as well. We found no statistically significant differences in the perception of the importance of not being afraid to take risks among the selected regions.

The values of test criteria $(p$-value $=0.2511 / 0.2372$ ) show that there are no significant differences in the structure of all responses we got in the selected regions. We discovered only partial, but interesting relations. For instance, entrepreneurs of the Bratislava region stated less often than entrepreneurs of the Trencin and Zilina regions that expertise is a vital feature ( $p$-value $=0.0135 / 0.0285)$ and more often they preferred optimism ( $p$-value $=0.0349 / 0.0151$ ).

The findings within our research are compatible with the conclusions of the presented studies, such as: Knörr, Alvarez and Urbano (2013), Caliendo, Fossen and Kritikos (2014), Ilouga, Mouloungni and Sahut (2014), Deáková et al. (2012), and Soininen et al. (2012).

We share the same opinion as Kvietok (2013) that a significant part of the motivation to take risks in business results from the motivation for success. To achieve the set goals, successful people are willing to take reasonable risks associated with the feedback about the level of achieved results. Entrepreneurs are sort of managed by an inner feeling, which means that they feel their personal fate is the result of their own efforts. They are independent, autonomous and rely upon themselves, which are the main characteristics of entrepreneurial personalities. Psychological research on entrepreneurs has shown that another characteristic feature of entrepreneurs is the ability to make decisions under conditions of uncertainty. Entrepreneurs are stimulated by success itself more than by money. Money is simply a measure of achievement and success.

Table 1: The Most Important Characteristics of an Entrepreneur

\begin{tabular}{|l|c|c|c|c|}
\hline $\begin{array}{l}\text { What qualities and skills must an entrepreneur have? } \\
\text { (Please give a maximum of up to three answers.) }\end{array}$ & $\begin{array}{c}\text { BA } \\
\text { in } \%\end{array}$ & $\begin{array}{c}\text { TN } \\
\text { in } \%\end{array}$ & $\begin{array}{c}\text { ZA } \\
\text { in } \%\end{array}$ & p-value: BA:TN/BA:ZA/TN:ZA \\
\hline 1. undeterred by risk & 53.92 & 59.05 & $\mathbf{5 1 . 8 3}$ & $0.4593 / 0.7414 / 0.4593$ \\
\hline 2. persistence & 44.12 & 40.00 & 38.41 & $0.5485 / 0.3576 / 0.7949$ \\
\hline 3. creativity & 18.63 & 18.10 & 27.44 & $0.9203 / 0.1031 / 0.0784$ \\
\hline 4. imagination & 3.92 & 5.71 & 7.32 & $0.5485 / 0.2585 / 0.6101$ \\
\hline 5. expertise & 36.27 & 53.33 & 50.00 & $\mathbf{0 . 0 1 3 5 / 0 . 0 2 8 5 / 0 . 5 9 6 1}$ \\
\hline 6. quality of education & 5.88 & 4.76 & 3.66 & $0.7188 / 0.3953 / 0.6527$ \\
\hline 7. intelligence & 9.80 & 7.62 & 12.20 & $0.5755 / 0.5485 / 0.2301$ \\
\hline 8. responsibility & 34.31 & 43.81 & 46.95 & $0.1615 / 0.0424 / 0.6171$ \\
\hline 9. intuition & 19.61 & 12.38 & 7.93 & $0.1556 / 0.0050 / 0.2263$ \\
\hline 10. decisiveness & 23.53 & 21.90 & 17.68 & $0.7795 / 0.2460 / 0.3898$ \\
\hline 11. patience & 19.61 & 19.05 & 17.68 & $0.9203 / 0.6965 / 0.7795$ \\
\hline 12. optimism & 18.63 & 8.57 & 8.54 & $\mathbf{0 . 0 3 4 9 / 0 . 0 1 5 1 / 0 . 9 9 2 0}$ \\
\hline 13. other & 2.94 & 1.90 & 0.61 & $0.6241 / 0.1285 / 0.3222$ \\
\hline p-value BA:TN/BA:ZA/TN:ZA & & & $0.2511 / 0.2372 / 0.2420$ \\
\hline
\end{tabular}

Source: Authors' data and calculation

To present the entrepreneurs' assessment of the State's approach towards them is the objective of Table 2 below. 
Table 2: The State Approach towards Entrepreneurs' Needs in the Selected Regions of Slovakia

\begin{tabular}{|l|c|c|c|c|}
\hline How do you assess the State's attitude to entrepreneurs' needs? & $\begin{array}{c}\text { BA } \\
\text { in \% }\end{array}$ & $\begin{array}{c}\text { TN } \\
\text { in \% }\end{array}$ & $\begin{array}{c}\text { ZA } \\
\text { in \% }\end{array}$ & $\begin{array}{c}\text { p-value: } \\
\text { BA:TN/BA:ZA/TN:ZA }\end{array}$ \\
\hline 1. I feel the State is just bullying us & $\mathbf{5 4 . 9 0}$ & $\mathbf{5 4 . 2 9}$ & $\mathbf{5 3 . 0 5}$ & $0.9283 / 0.7718 / 0.8415$ \\
\hline 2. The State is not fulfilling its duties & 40.20 & 40.95 & 38.41 & $0.9124 / 0.7718 / 0.6745$ \\
\hline 3. The State is fulfilling its duties & 3.92 & 4.76 & 5.49 & $0.7642 / 0.5619 / 0.7949$ \\
\hline 4. The State helps us in our business activities & 0.98 & 0.00 & 3.05 & $0.3077 / 0.2713 / 0.0703$ \\
\hline p-value BA:TN/BA:ZA/TN:ZA & & $0.7712 / 0.6595 / 0.3355$ \\
\hline
\end{tabular}

Source: Authors' data and calculation

Based on the results of our research, $\mathrm{H} 2$ was confirmed. In all the selected Slovak regions entrepreneurs frequently (more than 50\%) declared that the State is just bullying them (see the Table 2).

The values of the calculated test criteria showed there are no statistically significant differences in the assessment of the State's approach within the selected regions ( $p$-values $=0.7712 / 0.6595 / 0.3355)$.

On the contrary, only $4.90 \%$ (line $3+$ line 4 of the Table 2 ) of entrepreneurs in the Bratislava region, $4.76 \%$ of entrepreneurs in the Trencin region and $8.54 \%$ of entrepreneurs in the Zilina region think that the State fulfils its duties and helps them.

Our findings are in line with the conclusions of the Business Alliance of Slovakia (Podnikatel'ská aliancia Slovenska, 2012) and Slovak Chamber of Commerce (Slovenská obchodná a priemyselná komora, 2014).

We believe our research can be inspirational for politicians to form a more effective approach towards entrepreneurs. It is a paradox that politicians and experts are rather satisfied and intensively discuss the position of SMEs, but the real business practice confirms that there exists a lack of high quality SMEs business environment. Moreover, nothing has changed for a long time in Slovakia and the SMEs business environment is not properly set. Politicians, either in Slovakia or in the European Union, verbally declare their interest to solve the problems of SMEs. In fact, they perform the opposite actions. For example, there will be an application form for additional taxation from the next year in Slovakia, which may have a significant impact on the business activities of SMEs. Besides various taxes, companies will have to pay for a "business license" as well.

Table 3 is dealing further with the entrepreneurs' assessment of the State's approach, namely of the financial support from the State.

Table 3: The Assessment of the Financial Support of Entrepreneurs by the State

\begin{tabular}{|l|c|c|c|c|}
\hline Do you think the State should support entrepreneurs financially? & $\begin{array}{c}\text { BA } \\
\text { in } \%\end{array}$ & $\begin{array}{c}\text { TN } \\
\text { in } \%\end{array}$ & $\begin{array}{c}\text { ZA } \\
\text { in } \%\end{array}$ & $\begin{array}{c}\text { B-value: } \\
\text { BA:TN/BA:ZA/TN:ZA }\end{array}$ \\
\hline 1. Yes & 65.69 & 67.62 & 74.39 & $0.7718 / 0.1285 / 0.2301$ \\
\hline 2. No & 22.55 & 25.71 & 17.07 & $0.5961 / 0.2713 / 0.0873$ \\
\hline 3. I don't know & 11.76 & 6.67 & 8.54 & $0.2041 / 0.3898 / 0.5755$ \\
\hline p-value:BA:TN/BA:ZA/TN:ZA & \multicolumn{3}{|l|}{$0.4256 / 0.3128 / 0.2194$} \\
\hline
\end{tabular}

Source: Authors' data and calculation

Since more than $60 \%$ of entrepreneurs in all the selected regions stated that the State should support them financially, the validity of $\mathrm{H} 3$ was confirmed.

$\mathrm{H} 3 \mathrm{a}$ was also confirmed. The calculated test criteria ( $p$-value $=0.4256 / 0.3128 / 0.2194$ ) indicate no significant differences among the regions regarding this issue. Entrepreneurs in all the selected regions share about the same opinion on whether the State should support them financially or not.

Moreover, we examined the intensity of the State's financial support utilisation by entrepreneurs. The results are presented in the Table 4.

Table 4: The Entrepreneurs' Utilisation of the State Financial Support

\begin{tabular}{|l|c|c|c|c|}
\hline $\begin{array}{l}\text { Have you ever used any financial support from the State in } \\
\text { your business activities? }\end{array}$ & $\begin{array}{c}\text { BA } \\
\text { in } \%\end{array}$ & $\begin{array}{c}\text { TN } \\
\text { in } \%\end{array}$ & $\begin{array}{c}\text { ZA } \\
\text { in } \%\end{array}$ & $\begin{array}{c}\text { p-value: } \\
\text { BA:TN/BA:ZA/TN:ZA }\end{array}$ \\
\hline 1. Yes & 15.69 & $\mathbf{3 0 . 4 8}$ & $\mathbf{2 2 . 5 6}$ & $\mathbf{0 . 0 1 1 7 / 0 . 1 7 3 8 / 0 . 1 4 7 1}$ \\
\hline 2. No & 84.32 & 69.52 & 77.44 & $\mathbf{0 . 0 1 1 7 / 0 . 1 7 3 8 / 0 . 1 4 7 1}$ \\
\hline p-value BA:TN/BA:ZA/TN:ZA & & $\mathbf{0 . 0 1 1 7 / 0 . 1 7 3 8 / 0 . 1 4 7 1}$ \\
\hline
\end{tabular}

Source: Authors' data and calculation 
The validity of $\mathrm{H} 4$ was confirmed. The results of our research presented in Table 6 show the level of entrepreneurs' utilisation of State financial support is higher than $20 \%$ in the regions of Trencin and Zilina.

The validity of $\mathrm{H} 4 \mathrm{a}$ was partially confirmed. This hypothesis was valid for the comparison of the regions of Bratislava and Trencin ( $p$-value $=0.0117$ ) but significant variations between the Bratislava and Zilina region and between the Trencin and Zilina region were not found ( $p$-values $=0.1738 / 0.1471$ ). It is probable that these results are vastly influenced by the objectives of State financial support in Slovakia: the regions out of Bratislava are prioritised in obtaining money from the government and EU funds.

Furthermore, it would be appropriate to define boundaries between the public and the private sector and to reevaluate the existing forms of business environment deformations by the State such as various forms of subsidies, support programs and privileges in competitive environment. In terms of the market mechanism functioning, it is best if the market is able to regulate itself without any State intervention as much as possible. Probably the most important prerequisite for appropriate business environment should be a long-term and stable economic policy of the State including fair and stable tax environment. Unfortunately, it works differently in Slovakia. If the State does not have enough money, it immediately taxes entrepreneurs instead of reassessing the expenditure side of the budget.

Moreover, there are many cases in Slovakia in which it is obvious that the State's support for some companies is in fact a form of corruption. There are many firms doing their business exclusively in collaboration with the State. Therefore, it can be assumed that their motivation for running a business is not respectable.

Table 5 presents the results of our research regarding the entrepreneurs' opinion on the commercial banks' approach towards the financing of their companies.

Table 5: Commercial Banks' Approach to the SMEs Financing in the Selected Regions of Slovakia

\begin{tabular}{|l|c|c|c|c|}
\hline $\begin{array}{l}\text { How do you assess the banks' approach to the financing of small and } \\
\text { medium-sized enterprises? }\end{array}$ & $\begin{array}{c}\text { BA } \\
\text { in } \%\end{array}$ & $\begin{array}{c}\text { TN } \\
\text { in } \%\end{array}$ & $\begin{array}{c}\text { ZA } \\
\text { in \% }\end{array}$ & $\begin{array}{c}\text { p-value: } \\
\text { BA:TN/BA:ZA/TN:ZA }\end{array}$ \\
\hline 1. Banks fully accept our needs and have a good relationship with us ) & 1.96 & $\mathbf{0 . 9 5}$ & $\mathbf{3 . 0 5}$ & $0.5419 / 0.5892 / 0.2543$ \\
\hline 2. Banks behave appropriately & 33.33 & $\mathbf{3 4 . 2 9}$ & $\mathbf{2 0 . 1 2}$ & $0.8887 / 0.0160 / 0.0096$ \\
\hline 3. Banks are unhelpful & 10.78 & 9.52 & 14.02 & $0.7642 / 0.4413 / 0.2713$ \\
\hline 4. Banks use unmeetable criteria for lending & 34.31 & 43.81 & 37.20 & $0.1615 / 0.6312 / 0.2801$ \\
\hline 5. I cannot judge & 19.62 & 11.43 & 25.61 & $0.1031 / 0.2585 / 0.0047$ \\
\hline p-value BA:TN/BA:ZA/TN:ZA & \multicolumn{3}{|l|}{$0.4212 / 0.1796 / 0.0060$} \\
\hline
\end{tabular}

Source: Authors' data and calculation

As the results of our research show, the validity of $\mathrm{H} 5$ was confirmed. In more details, only $35.29 \%$ (line $1+$ line 2 in the Table 5) of the Bratislava region entrepreneurs assess the commercial banks' approach to their financing positively. The shares of satisfied entrepreneurs were even lower in the other two regions, namely $35.24 \%$ in the Trencin region and $23.17 \%$ in the Zilina region.

On the other hand, it was not possible to confirm H5a. The calculated p-values indicate no differences in the negative assessment of the commercial banks' approach towards the financing of SMEs within the selected regions (see Table 5, line 3 and 4).

Within our research, we asked entrepreneurs how the lending policies of commercial banks have changed compared to the pre-crisis period. $36.28 \%$ of the Bratislava region entrepreneurs stated the approach of banks has worsened compared to 2008 and only $8.82 \%$ stated the approach has improved. $14.71 \%$ of them declared no difference in the approach and $40.20 \%$ could not answer this question. Similar results were obtained in the other two regions. $47.62 \%$ of the Trencin region entrepreneurs stated the approach has worsened, whereas $11.43 \%$ stated the approach has improved. $31.10 \%$ of entrepreneurs in the Zilina region declared a worse attitude of banks and $12.20 \%$ of them a better commercial banks' attitude compared to 2008. These findings are compatible with the studies of the European Commission (2011), Di Giuli, Caselli and Gatti (2011), Covaci (2008), Dierkes et al. (2013), Kirschenmann and Norden (2012), and Neuberger a Räthke (2009).

Considering the specific conditions of the commercial bank sector, such as doing business with mostly external money and having equity capital only to cover financial risks, it is natural that banks have to protect the money of their depositors. Thus, it seems logical that banks tightened their lending policies as an answer to the global financial crisis. Nonetheless, it can be argued that some of them have changed their behaviour towards debtors from one extreme to another. Before crisis, banks were almost pushing their clients to take out new loans and shortly after, they wanted these 
clients to pay the loans back as soon as possible.

Furthermore in our research, we examined the decrease in the profitability of companies during the crisis as it has tremendous influence on the company's credibility. We found out the average profitability decrease was at $12.12 \%$ in the Bratislava region, at $14.04 \%$ in the Trencin region and at $12.01 \%$ in the Zilina region.

\section{Conclusion}

The aim of this article was to define, quantify and compare significant attributes of the creation and development of the business environment for SMEs in the selected regions of Slovakia.

Our research showed there are certain regional variations in the assessment of important attributes of the SME segment in Slovakia. Comparing the Bratislava region as the most economically developed to the other selected regions, we found significant differences in identifying vital personal features and skills of an entrepreneur. Certain variations were discovered also in the entrepreneurs' utilisation of State financial support.

At the same time, there are several factors not significantly influenced by regional characteristics. These is the general State approach towards entrepreneurs, the assessment of State financial support, the opinion on the attitude of commercial banks in relation to SME financing.

It also has to be pointed out that entrepreneurs in the Bratislava region stated optimism as a vital quality of an entrepreneur more often than entrepreneurs in the other regions. At the same time, they declared expertise less often than entrepreneurs in the other regions.

Moreover, entrepreneurs assess the State's role in creating business environment rather negatively. Thus, the research results imply the need to improve the State's approach to entrepreneurship, to create a better image of business activities in the eyes of society and to awaken public interest in conducting business.

Although it is clear that there are certain limitations to our research (e.g. the number of companies involved in the research), we believe that our article has inferred significant incentives for the formation of a more appropriate business environment for SMEs in Slovakia.

Our future research will focus on the examination of the relationships among personal characteristics of entrepreneurs, the propensity to take risks and their financial performance.

\section{Acknowledgement}

This paper was supported by Project No. FaME/2013/MSPRISK: Current trends in the area of business risks of small and medium-sized enterprises in selected regions of the Czech Republic and Slovakia

\section{References}

Almeida, P.I.L., Ahmetoglu, G., Chamorro-Premuzic, T. (2014). Who Wants to Be an Entrepreneur? The Relationship Between Vocational Interests and Individual Differences in Entrepreneurship. Journal of Career Assessment, 22(1): $102-112$. http://dx.doi.org/10.1177/069072713492923

Belás, J., Bartoš, P., Habánik, J., Novák, P. (2014), Significant Attributes of the Business Environment in Small and Meduim-Sized Enterprises, Economics and Sociology, Vol. 7, No 3, pp. 22-39. DOI: 10.14254/2071-789X.2014/7-3/2

Boso, N., Story, V. M., Cadogan, J. W. (2013). Entrepreneurial orientation, market orientation, network ties, and performance: Study of entrepreneurial firms in a developing economy. Journalof Business Venturing, 28, 708-727. http://dx.doi.org/10.1016/j.jbusvent.2013.04.001

Bratislavský samosprávny kraj. (2014). Informácie o kraji. Retrieved from http://www.region-bsk.sk/clanok/informacie-o-kraji126328.aspx

Brockman, B. K., Jones, M. A., Becherer, R. C. (2012), Customer Orientation and Performance in Small Firms: Examining the Moderating Influence of Risk-Taking, Innovativeness, and Opportunity Focus. Journal of Small Business Management, 50: 429446. http://dx.doi.org/10.1111/j.1540-627X.2012.00361.x

Caliendo, M., Fossen, F., Kritikos, A. S. (2014). Personality characteristics and the decisions to become and stayself-employed. Small Bus Econ 42, 787-814. http://dx.doi.org/10.1007/s11187-013-9514-8

Canales, R., Nanda, R. (2012). A darker side to decentralized banks: Market power and credit rationing in SME lending. Journal of Financial Economics, 105: 353-366. http://dx.doi.org/10.1016/j.fineco 2012.03.006.

Covaci, B. (2008). Credit Risk in Financing SME in Romania. Bucharest: Spiru Haret University. Retrieved from http://papers.ssrn.com/sol3/papers.cfm?abstract_id=1313879

Deáková, K., Drážovská, K., Grznárik, D., Kondášová, I. (2010). Podnikanie. Bratislava: SOPK.

Dierkes, M., Erner, C., Langer, T., Norden, L. (2013). Business credit information sparing and default risk of private firms. Journal of 
Banking \& Finance, 37: 2867-2878. http://dx.doi.org/10.1016/j.jbankfin

Di Giuli, A., Caselli, S., Gatti, S. (2011). Are small family firms financially sophisticated? Journal of Banking \& Finance, 35: 2931-2944. http://dx.doi.org/10.1016/j.jbankfin

Gallardo-Vazquez, D., Sanchez-Hernandez, I. (2012) Information on Corporate Social Responsibility and SME's Environmental Responsiveness: A Regional Study, Economics and Sociology, Vol. 5, No 2, pp. 103-115.

Gaweł, A. (2010) The Relationship between Entrepreneurship and Unemployment in the Business Cycle, Journal of International Studies, Vol. 3, No 1, pp. 59-69.

Eggers, F., Kraus, S., Hughes, M., Laraway, E., Snycerski, S. (2013). Implications of customer and entrepreneurial orientations for SME growth. Management Decision, 51 (3): 524-546. http://dx.doi.org/10.1108/00251741311309643

Evropská komise. (2011). Velké záměry pro male podniky-co dělá EU pro MSP. Lucemburk: Úráad pro publikace EU.

Hvide, H.K., Panos, G. A. (2014). Risk tolerance and entrepreneurship. Journal of Financial Economics, 111: 200 - 223.

llouga, S.N., Mouloungni, A.C.N., Sahut, J.M. (2014). Entrepreneurial intention and career choices: the role of volition. Small Bus Econ, 42: $717-728$.

Kirschenbaum, K., Norden, L. (2012). The Relationship between Borrower Risk and Loan Maturity in Small Business Lending. Journal of Business Finance \& Accounting, 39(5-6): 730-757. http://dx.doi.org/10.1111/j.1468-5957.2012.02285.x

Knörr, H., Alvarez, C., Urbano, D. (2013). Entrepreneurs or employees: a cross-cultural cognitive analysis. Int Entrep Manag J, 9: 273294. http://dx.doi.org/10.1007/s11365-012-0235-2

Kvietok, A. (2013). Psychologický profil podnikatela. http://www.psyx.cz/texty/psychologicky-profil-podnikatele.php

Lasagni, A. (2012). How Can External Relationships Enhance Innovation in SMEs? New Evidence for Europe. Journal of Small Business Management, 50: 310-339. http://dx.doi.org/10.1111/j.1540-627X.2012.00355.x.

Lofstrom, M., Bates, T., Parker, S.C. (2014). Why are some people more likely to become small-businesses owners than others: Entrepreneurship entry and industry-specific barriers. Journal of Business Venturing, 29: 232-251. http://dx.doi.org/10.1016/j.jbusvent. 2013.01.004.

Sobeková Majková, M., Solík, J., Sipko, J. (2014), The Analysis of Chosen Business Obstacles and Problems with the Financing of Young Entrepreneurs in Slovakia, Economics and Sociology, Vol. 7, No 3, pp. 90-103. DOI: 10.14254/2071-789X.2014/7-3/7

Moro, A., Fink, M. (2013). Loan managers' trust and credit access for SMEs. Journal of Banking \& Finance, 37: 927-936.

Národná agentúra pre rozvoj malého a stredného podnikania. (2013). Správa o stave malého a stredného podnikania v Slovenskej republike $v$ roku 2012. Bratislava: NADSME.

Národná agentúra pre rozvoj malého a stredného podnikania. (2010). Názory verejnosti na podnikanie a podnikatelov v Slovenskej republike. Bratislava: NADSME.

Neuberger, D., Räthke, S. (2009). Microenterprises and multiple relationships: The case of professionals. Small Business Economics, Vol.32, pp. 207-229. http://dx.doi.org/10.1007/s11187-007-9076-8

Podnikatel'ská aliancia Slovenska. (2012). Podnikatel'ské prostredie sa zhoršuje. I/http://spravy.pravda.sk/ekonomika/clanok/199136pas-podnikatelske prostredie-sa-nadalej-zhorsuje/

Slovenská obchodná a priemyselná komora. (2014). Firmy vnímajú podnikatel'ské prostredie na Slovensku negatívne. Bratislava: SOPK.

Soininen, J., Martikainen, M., Puumalainen, K., Kyläheiko, K. (2012). Entrepreneurial orientation: Growth and profitability of Finnish small- and medium-sized enterprises. Int. J. Production Economics, 140: 614-621. http://dx.doi.org/10.1016/j.jpe. 2011.05.029.

Stuetzer, M., Obschonka, M., Brixy, U., Sternberg, R., Cantner, U. (2014). Regional characteristics, opportunity perception and entrepreneurial activities: The Role of Organizational Learning Capability and Innovation Performance. Small Business Economics, 42(2): 221-244. http://dx.doi.org/10.1007/s11187-013-9488-6 